\title{
THE NEW METHOD OF PELVIC PACKING AGAINST CONTINUING INTRAPELVIC BLEEDING RESULTING FROM THE UNSTABLE PELVIC RING FRACTURES
}

\author{
Egiazaryan KA1, Gordienko DI ${ }^{1}$, Starchik DA², Lysko $\mathrm{AM}^{1}{ }^{1 凶}$ \\ ${ }_{1}^{1}$ Pirogov Russian National Research Medical University, Moscow, Russia \\ ${ }^{2}$ Mechnikov North-Western State Medical University, Saint-Peterburg, Russia
}

\begin{abstract}
Unstable pelvic ring fractures are one of the common causes of death of patients with concomitant injuries. The existing methods applied to treat such conditions can cause a number of complications and have contraindications. We have described a successful clinical case of intrapelvic hemorrhage arrest in a patient with multiple injuries. in this case, we applied the new method combining minimally invasive angioembolization and easily applicable and effective balloon tamponade.
\end{abstract}

Keywords: concomitant injury, multiple injury, polytrauma, intrapelvic bleeding, pelvic packing

Author contribution: Egiazaryan KA, Gordienko DI — study organization and planning; Starchik DA — study planning, anatomical examination; Lysko AM — literature analysis, data collection, analysis, interpretation, surgery.

Compliance with ethical standards: the study was approved by the Ethics Committee of Pirogov City Clinical Hospital № 1 (minutes № 5 of May 28, 2018) and Ethics Committee of Pirogov Russian National Research Medical University (minutes № 170 of December 18, 2017).

$\triangle$ Correspondence should be addressed: Artyom M. Lysko

Khachaturiana 12-3, Moscow, 127562; ArtLysko@gmail.com

Received: 03.03.2019 Accepted: 16.04.2019 Published online: 29.04.2019

DOI: $10.24075 /$ brsmu.2019.031

\section{НОВЫЙ СПОСОБ ТАМПОНАДЫ ТАЗА ПРИ ПРОДОЛЖАЮЩЕМСЯ ВНУТРИТАЗОВОМ КРОВОТЕЧЕНИИ}

К. А. Егиазарян ${ }^{1}$, Д. И. Гордиенко ${ }^{1}$, Д. А. Старчик², А. М. Лыско

${ }^{1}$ Российский национальный исследовательский медицинский университет имени Н. И. Пирогова, Москва, Россия

${ }^{2}$ Северо-Западный государственный медицинский университет имени И. И. Мечникова, Санкт-Петербург, Россия

Нестабильные повреждения тазового кольца продолжают оставаться одной из наиболее частых причин летального исхода у пациентов с сочетанной травмой, а существующие способы имеют ряд осложнений и противопоказаний. Нами описан успешный клинический случай остановки внутритазового кровотечения у пациента с множественными травмами, в котором с целью объединения преимуществ малой инвазивности ангиоэмболизации, простоты исполнения и воздействия на основную причину кровопотери тампонады таза применен новый способ внутритазовой остановки кровотечения при помощи баллонных устройств.

Ключевые слова: сочетанная травма, множественная травма, политравма, переломы костей таза, внутритазовое кровотечение, тампонада таза

Информация о вкладе авторов: К. А. Егиазарян, Д. И. Гордиенко - организация и планирование исследования; Д. А. Старчик - планирование исследования, выполнение анатомического исследования; А. М. Лыско - анализ литературы, сбор, анализ, интерпретация данных, выполнение оперативного вмешательства

Соблюдение этических стандартов: исследование одобрено этическим комитетом городской клинической больницы № 1 имени Н. И. Пирогова (протокол № 5 от 28 мая 2018 г.) и этическим комитетом РНИМУ имени Н. И. Пирогова (протокол № 170 от 18 декабря 2017 г.)

$\triangle$ Для корреспонденции: Артём Михайлович Лыско

ул. Хачатуряна, д. 12, корп. 3, г. Москва, 127562; ArtLysko@gmail.com

Статья получена: 03.03.2019 Статья принята к печати: 16.04.2019 Опубликована онлайн: 29.04.2019

DOI: $10.24075 /$ vrgmu.2019.0xx

The considerably high mortality rate, medical and social consequences associated with unstable pelvic ring injuries make the problem of arresting intrapelvic hemorrhage an urgent one [1]. Latest research shows that in $25 \%$ of cases pelvic ring damage is concomitant with other injuries [2-4]. Up to $60 \%$ of such situation end in death; in every third case the, the reason is unarrested pelvic hemorrhage [5-9].

Over the years, practitioners and scholars have developed and improved a number of methods to arrest pelvic hemorrhage, including angioembolization, pelvic tamponade and REBOA (Resuscitative Endovascular Balloon Occlusion of the Aorta) [10-16]. All of them are unique, and each has both positive and negative aspects. Pelvic tamponade arrests venous bleeding, which is a more common condition; the procedure is invasive, implies considerable blood loss and poses a risk of infection. Angioembolization can cause ischemic damage, which leads to necrosis and intracranial hemorrhage [17-22]. We have developed a new pelvic hemorrhage arrest method that combines minimal invasiveness of angioembolization and pelvic tamponade's ease of application and blood stopping properties. The idea behind the new method is a derivative of the uterine balloon tamponade commonly used in obstetrics and gynecology to arrest uncontrolled intrauterine hemorrhages [23].

\section{Description of the clinical case}

Patient S., 26 years old, a construction worker, suffered a fall from the 2nd floor (height of about 12 meters) onto a concrete slab. Pre-hospital, the patient received infusions and analgesics. On admission, he was intubated, his bladder and veins catheterized, emergency infusions and analgesics replaced with more adequate solutions; his arterial blood pressure (ABP) was 
of $107 / 70 \mathrm{mmHg}$, heart rate -113 beats per minute, diuresis rate normal. The patient's Glasgow Coma Scale score was 9. Laboratory tests have shown that his hemoglobin and hemotacritis were normal with pronounced leukocytosis (up to 29.9 • 10\%/l), alkalipenia $(9.8 \mathrm{mmol} / \mathrm{l})$ and lactate of $4.8 \mathrm{mmol} / \mathrm{l}$ in the background. Ultrasound examination revealed no fluid in pleural and abdominal cavities and a small amount in the pelvic cavity. The patient's hemodynamics at admission was stable, his pelvic ring showed clinical signs of mechanical instability, therefore, he received a pelvic bandage and was sent to the PAN CT examination (whole body computed tomography), which revealed a $\mathrm{C} 1$ concomitant pelvic ring injury according to AO (Arbeitsgemeinschaft für Osteosynthesefragen) / OTA (Orthopedic Trauma Association) classification (Fig. 1). Also, he suffered a closed head injury, parietal brain lobe contusion (right), fractures of the nose bones, left orbit walls, closed fractures of the right shoulder's large tubercle with slight displacement of the fragments, Lisfranc injury (right foot), scrotal hematoma (ISS = 29 points).

During the CT examination, the patient's ABP dropped abruptly to $60 / 30 \mathrm{mmHg}$ and heart rate increased to 150 beats per minute; he was given $0.3 \mu \mathrm{g} / \mathrm{kg} / \mathrm{min}$ of $0.2 \%$ norepinephrine (vasopressor support) and urgently taken to the operating room to stabilize the front of the pelvic ring with an external fixation device placed over acetabulum and to apply a C-shaped frame to the back of the pelvic ring. The emergency measures taken to stabilize the pelvic ring raised the patient's ABP to $85 / 40 \mathrm{mmHg}$ and reduced his heart rate to 130 beats per minute. The vasopressor support was continued. After mechanical stabilization of the pelvic ring, hemodynamic instability persisted for 15 minutes, which lead us to a decision to arrest hemorrhage therein with the help of a balloon (balloon tamponade). We injected anesthetic solutions into the soft tissues of the access incision area and made a puncture-cut measuring 2-3 cm directly above the pubic symphysis and along the anterior midline of the body. Using blunt instruments, we separated subcutaneous tissue, reached the pyramidal muscle and separated its fibers the same way, then introduced a trocar with a mandrin into retropubic space. Next, the trocar was guided paravesically towards left or right sacroiliac joint in the corresponding lateral cellular tissue space (Fig. 2). Once the mandrin was removed, we inserted the balloon device along the trocar, which was a Zhukovsky balloon (Ginamed, Russia) used to arrest intrauterine bleeding. The device includes a plastic frame up to $25 \mathrm{~cm}$ long and up to $8 \mathrm{~mm}$ in diameter, and a rubber balloon measuring up to $11.5 \mathrm{~cm}$. Then the trocar was removed, and the protocol was repeated in the opposite direction. The balloons were filled with sterile saline simultaneously. During filling, the resistance felt on the piston of the Janet's syringe was gradually increasing; when the balloons received $110 \mathrm{ml}$, the piston started moving backwards, which we took as a sign of sufficiency of the inflation. To monitor position and integrity of the balloon devices we made intraoperative $\mathrm{X}$-ray scans with the help of Phillips BV Endura (Netherlands) imaging system (Fig. 3). The ends of the balloon devices were kept outside; the wound was layer sutured (Fig. 4). The minimally invasive pelvis tamponade done as described above raised the patient's ABP to $110 / 47 \mathrm{mmHg}$ and decreased his heart rate to 115 beats per minute. The patient was transferred to the intensive care unit soon after surgery. in the course of the first 24 hours, his hemodynamics stabilized at 115/70 $\mathrm{mmHg}$, heart rate - at 100-110 beats per minute. By the end of the first day vasopressor support was gradually discontinued. Table describes the dynamics of the patient's condition indicators. Diuresis was at a sufficient level, with no signs of bleeding. Forty-eight hours after admission, with the patient's hemodynamic and laboratory test indicators stable, we decided to deflate the balloons by $50 \mathrm{ml}$ while continuing to monitor his condition. Since his condition was stable, on the third day it was decided to dismantle the C-shaped frame and lock the posterior sections of the pelvis with a screw, as well as to remove the balloons from the true pelvis cavity (Fig. 5). On the fifth day after admission, the patient was transferred to the specialized traumatology and orthopedics department for further treatment with daily checkups of the operative wound. It was healing with primary intention and showing no signs of inflammation and pathological discharge, which allowed final stabilization of the pelvic ring on the 10th day and transferring the patient to outpatient care on 16th day (Fig. 6, 7).

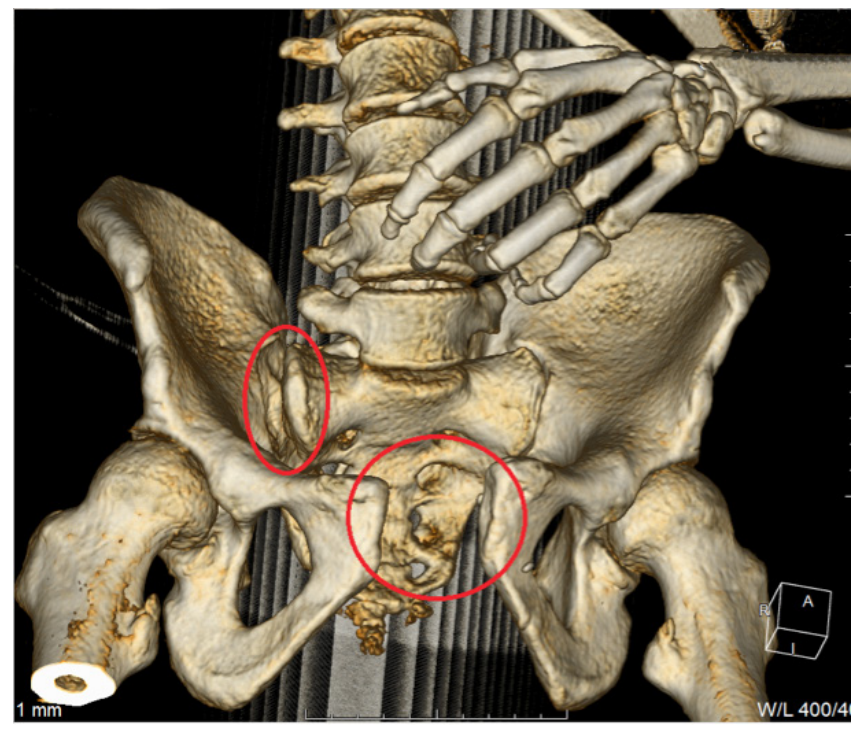

Fig. 1. 3D CT model of the pelvic ring injury: red ovals show the right sacroiliac joint rupture and the pubic symphysis rupture

Table. Dynamics of the patient's condition indicators before and after surgery

\begin{tabular}{|l|c|c|c|}
\hline \multicolumn{1}{|c|}{ Indicator/time } & Admission & First hour after surgery & $\begin{array}{c}\text { End of the first 24 hours } \\
\text { from admission }\end{array}$ \\
\hline ABP $(\mathrm{mmHg})$ & $60 / 30$ & $110 / 47$ & $115 / 70$ \\
\hline Heart rate (beats/min) & 150 & 115 & $100-110$ \\
\hline Hemoglobin $(\mathrm{g} / \mathrm{l})$ & 149 & 128 & 92 \\
\hline Hematocrit $(\%)$ & 44.2 & 38.4 & 27.2 \\
\hline Leukocytosis $\left(10^{9} / \mathrm{l}\right)$ & 29.9 & 33 & 11 \\
\hline Lactate $(\mathrm{mmol} / \mathrm{l})$ & 4.8 & 7.4 & 2.8 \\
\hline Alkalipenia $(\mathrm{mmol} / \mathrm{l})$ & -9.8 & -14 & -2.7 \\
\hline
\end{tabular}




\section{Discussion of the clinical case}

International community issues guidelines covering treatment of patients with unstable pelvic ring injuries on a regular basis. The most relevant of such guidelines recommend mechanical stabilization of the pelvic ring by external fixation devices as the first step and intrapelvic hemorrhage arrest as the second one, with preference given to tamponade since venous bleeding occurs in 8 out of 10 cases while arterial bleeding is registered in every 2 out of 10 cases only [24]. If pelvic tamponade does not stabilize the patient's hemodynamics, it is recommended to perform angioembolization of the bleeding vessels through a catheter [24]. According to the guidelines, if the patient's injuries cause both mechanical and hemodynamic instability, it is necessary to first stabilize the pelvic ring mechanically and then tamponade the cavity, as we did in the clinical case described above. In that case, this intervention was sufficient to stabilize hemodynamics. Another advantage of the developed method is the ability to control inflation of the balloon devices,

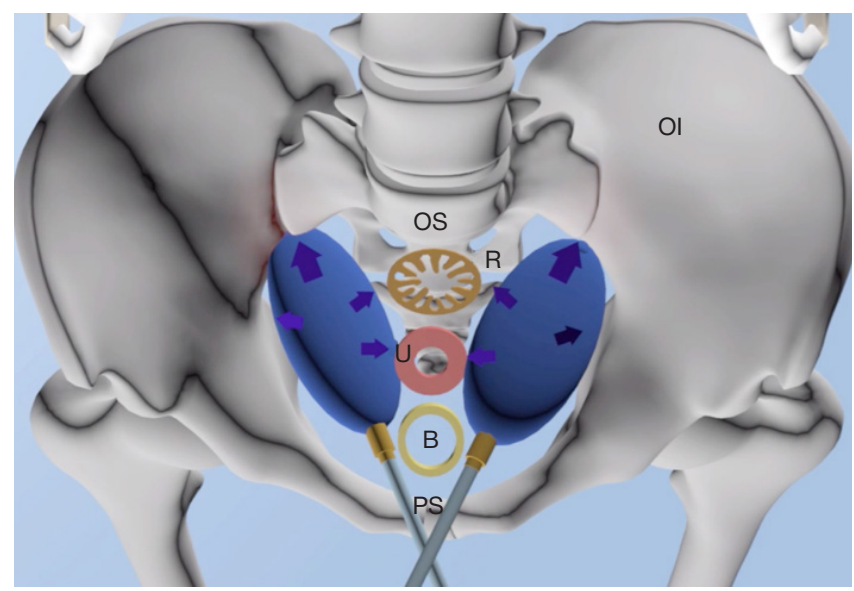

Fig. 2. Schematic representation of the direction of installation of balloon devices in the pelvic cavity: $\mathrm{B}$ - bladder, $\mathrm{U}$ - uterus, $\mathrm{R}$ - rectum, OS — sacrum, Oi — os innominatum, PS - pubic symphysis. The balloons deployed in the lateral space of the pelvis is in blue

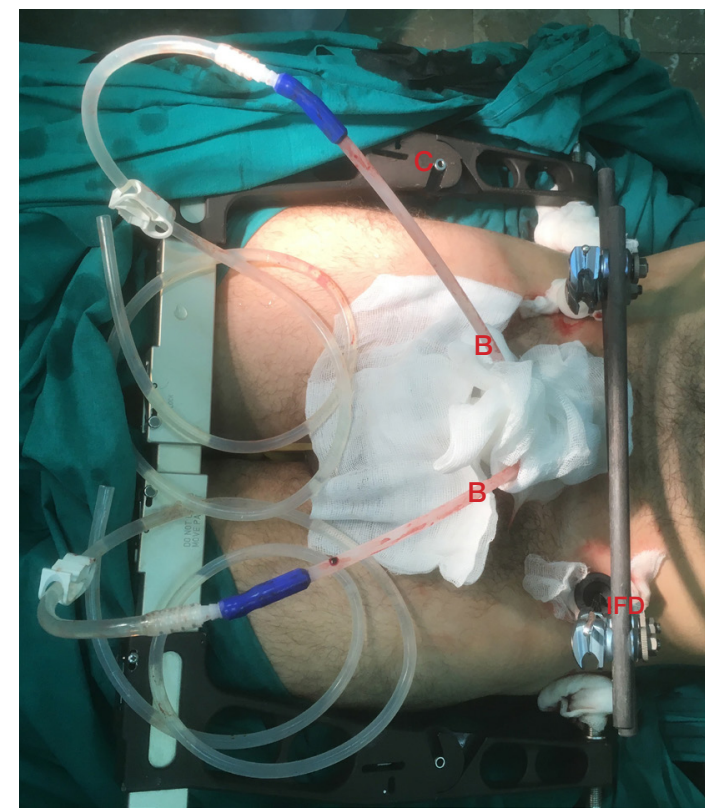

Fig. 4. External appearance of the patient's pelvic region with unstable pelvic ring injury and development of intrapelvic hemorrhage after stabilization by external fixation devices and deployment of the balloon devices in pelvic cavity: $\mathrm{C}$ - C-shaped frame for the back of the ring, IFD - External Fixation Device for the front, $\mathrm{B}$ - balloon devices which allows gradually deflating them as soon as 24 hours after deployment while monitoring hemodynamic indicators and learning the source of bleeding. Use of sterile and neutral saline solution is an equally important aspect: if the balloon breaks, the solution flowing out of it into the body will do no harm, which reduces the risk of complications.

It should be noted that the global trend to minimize invasion during medical interventions is obvious in pelvic surgery, too. A paper published in 2015 describes a clinical case of a small pelvic tamponade through bladder catheterization and inflation with 500-600 $\mathrm{ml}$ of normal saline [25]. There was an absolute contraindication to this method, however: violation of the urinary tract's integrity. Tamponade with a filled bladder in the early postoperative period allowed stabilization of the patient's hemodynamics, but, with the signs of renal failure becoming more vivid, bladder had to be deflated, which lead to destabilization of the patient's hemodynamics and laparotomy. in December 2016, a group of researchers conducted an animal experiment and published the results

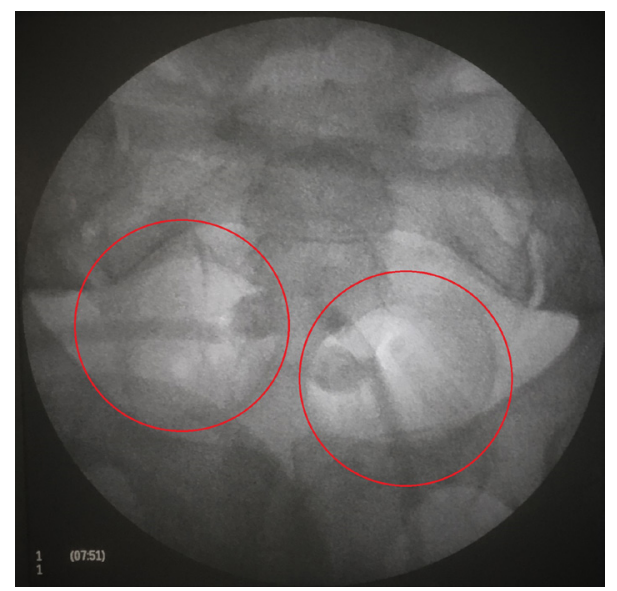

Fig. 3. Intraoperative patient's pelvis X-ray scan, unstable pelvic ring damage and development of intrapelvic hemorrhage after stabilization by external fixation devices and deployment of the balloon devices in the pelvic cavity (balloons circled by red)

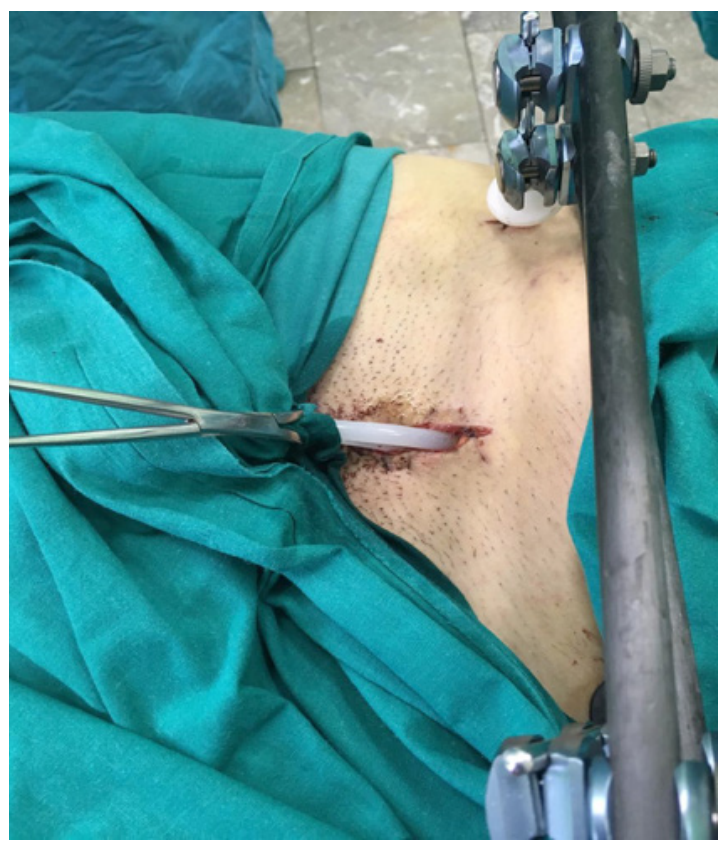

Fig. 5. Appearance of the patient's wound with tubes of balloon devices, before removal, 3rd day. The wound has no signs of inflammation; there is no pathological discharge along the balloon devices. in the right half of the picture external fixation device on the front of the pelvic ring 


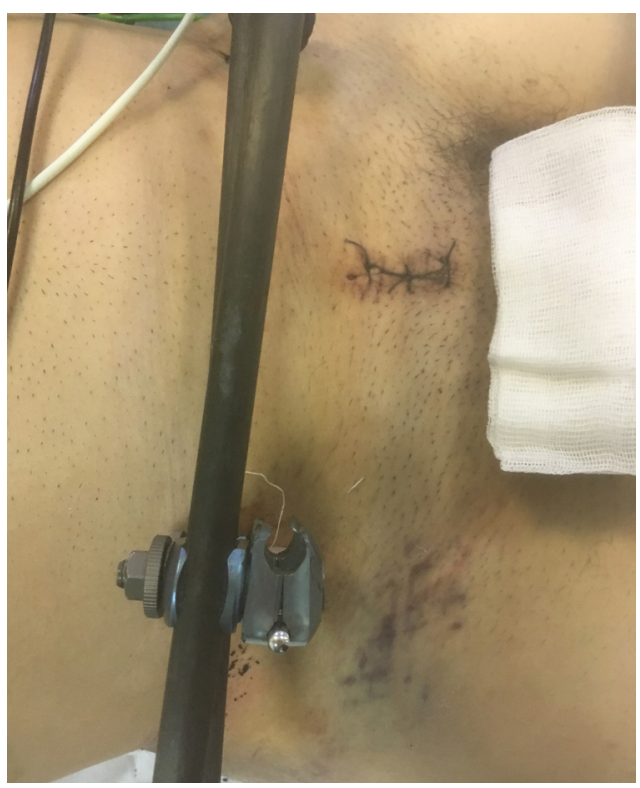

Fig. 6. Postoperative wound, first day after removal of the balloon devices. The postoperative wound heals by primary intention, without signs of inflammation and pathologic discharge; the sutures are consistent. In the left half of the picture external fixation device on the front of the pelvic ring

thereof, suggesting to tamponade pelvis with a balloon device in the perivascular space [26]. The test group in this experiment was compared to the regular pelvis tamponade group and the control group (no pelvic bleeding arrest); the comparison proved balloon tamponade to be a minimally invasive and effective method. However, it should be noted that placing the

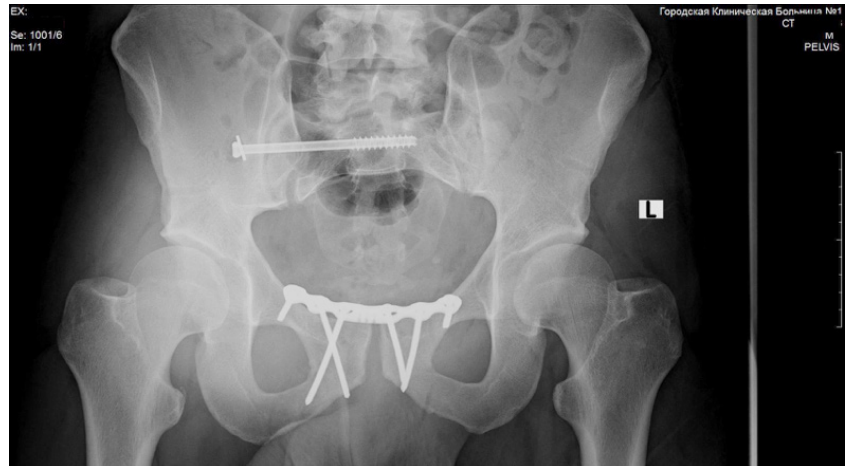

Fig. 7. X-rau scan of the patient's pelvis after the final stabilization of the pelvic ring (10th day): right sacroiliac joint fixed with a spongy screw with partial cutting and a washer, pubic symphysis — with plate and screws

balloon in the anterior small pelvis can cause displacement of the floating bone ring fragments that cannot be immobilized externally, as well as push the internal organs into the back sections of the pelvis where they can be punctured by bone fragments, and the excessive pressure applied to the bladder can rupture and damage urethra. We believe that twin balloons placed symmetrically in the lateral cellular spaces can prevent development of such complications.

\section{CONCLUSIONS}

The method we developed shows promise because it is minimally invasive, offers limited damage and control over the pressure. We hope that this method will be practiced to treat patients with unstable pelvic ring injuries.

\section{References}

1. Smoljar AN. Diagnostic and treatment of traumatic retroperitoneal hemorrhages [dissertation]. M., 2012-272. In Russian.

2. Burkhardt $M$, Kristen $A$, Culemann $U$, Koehler D, Histing $T$, Holstein J, et al. Pelvic fracture in multiple trauma: Are we still upto-date with massive fluid resuscitation? Injury. 2014; (45): S70-5.

3. Esmer E, Esmer E, Derst P, Schulz M, Siekmann H, Delank K. Einfluss der externen Beckenstabilisierung bei hämodynamisch instabilen Beckenfrakturen. Der Unfallchirurg. 2015; 120 (4): 312-9.

4. Wohlrath B, Trentzsch H, Hoffmann R, Kremer M, SchmidtHorlohè K, Schweigkofler U. Preclinical and clinical treatment of instable pelvic injuries: Results of an online survey. Der Unfallchirurg. 2014; 119 (9): 755-62. In German.

5. Holcomb J, del Junco D, Fox E, Wade C, Cohen M, Schreiber M, et al. The Prospective, Observational, Multicenter, Major Trauma Transfusion (PROMMTT) Study. JAMA Surgery. 2013; 48 (2): 27.

6. Guerado E, Bertrand M, Valdes L, Cruz E, Cano J. Resuscitation of Polytrauma Patients: The Management of Massive Skeletal Bleeding. The Open Orthopaedics Journal. 2015; 9 (1): 283-95.

7. Costantini T, Coimbra R, Holcomb J, Podbielski J, Catalano R, Blackburn A, et al. Current management of hemorrhage from severe pelvic fractures. Journal of Trauma and Acute Care Surgery. 2016; 80 (5): 717-25.

8. Burlew C, Moore E, Stahel P, Geddes A, Wagenaar A, Pieracci F, et al. Preperitoneal pelvic packing reduces mortality in patients with life-threatening hemorrhage due to unstable pelvic fractures. Journal of Trauma and Acute Care Surgery. 2017; 82 (2): 233-42.

9. Tesoriero R, Bruns B, Narayan M, Dubose J, Guliani S, Brenner M, et al. Angiographic embolization for hemorrhage following pelvic fracture. Journal of Trauma and Acute Care Surgery. 2017; 82 (1): 18-26.

10. Fajn AM. Diagnostic and treatment of severe pelvic fractures by patients with concomitant and multiple injuries. [dissertation]. M., 2017-238. Russian.

11. Guerado E, Medina A, Mata M, Galvan J, Bertrand M. Protocols for massive blood transfusion: when and why, and potential complications. European Journal of Trauma and Emergency Surgery. 2015; 42 (3): 283-95.

12. Margolies M, Ring E, Waltman A, Kerr W, Baum S. Arteriography in the Management of Hemorrhage from Pelvic Fractures. New England Journal of Medicine. 1972; 287 (7): 317-21.

13. Pohlemann T, Gansslen A, Bosch U, Tscherne H. The Technique of Packing for Control of Hemorrhage in Complex Pelvic Fractures. Techniques in Orthopaedics. 1994; 9 (4): 267-70.

14. Smith W, Moore E, Osborn P, Agudelo J, Morgan S, Parekh A, et al. Retroperitoneal Packing as a Resuscitation Technique for Hemodynamically Unstable Patients with Pelvic Fractures: Report of Two Representative Cases and a Description of Technique. The Journal of Trauma: Injury, Infection, and Critical Care. 2005; 59 (6): 1510-4.

15. Hughes C. W. Use of an intra-aortic balloon catheter tamponade for controlling intra-abdominal hemorrhage in man. Surgery. 1954; 36 (1): 65-8.

16. DuBose J, Scalea T, Brenner M, Skiada D, Inaba K, Cannon J, et al. The AAST prospective Aortic Occlusion for Resuscitation in Trauma and Acute Care Surgery (AORTA) registry. Journal of Trauma and Acute Care Surgery. 2016; 81 (3): 409-19.

17. Matityahu A, Marmor M, Elson J, Lieber C, Rogalski G, Lin C et al. Acute Complications of Patients With Pelvic Fractures After Pelvic Angiographic Embolization. Clinical Orthopaedics and Related Research. 2013; 471 (9): 2906-11.

18. Salcedo E, Brown I, Corwin M, Galante J. Pelvic angioembolization 
in trauma - Indications and outcomes. International Journal of Surgery. 2016; 33: 231-6.

19. Rudloff M, Triantafillou K. Management of Pelvic Ring Injuries in Unstable Patients. Orthopedic Clinics of North America. 2016; 47 (3): 551-63.

20. Saito N, Matsumoto H, Yagi T, Hara Y, Hayashida K, Motomura T, et al. Evaluation of the safety and feasibility of resuscitative endovascular balloon occlusion of the aorta. Journal of Trauma and Acute Care Surgery. 2015; 78 (5): 897-904.

21. Davidson A, Russo R, Reva V, Brenner M, Moore L, Ball C, et al. The pitfalls of resuscitative endovascular balloon occlusion of the aorta. Journal of Trauma and Acute Care Surgery. 2018; 84 (1): 192-202.

22. Uchino H, Tamura N, Echigoya R, Ikegami T, Fukuoka T. "REBOA" Is it Really Safe? A Case with Massive Intracranial Hemorrhage Possibly due to Endovascular Balloon Occlusion of the Aorta
(REBOA). American Journal of Case Reports. 2016; (17): 810-3. 23. Charoenkwan K. Effective use of the Bakri postpartum balloon for posthysterectomy pelvic floor hemorrhage. American Journal of Obstetrics and Gynecology. 2014; 210 (6): 586.

24. Coccolini F, Stahel P, Montori G, Biffl W, Horer T, Catena F, et al. Pelvic trauma: WSES classification and guidelines. World Journal of Emergency Surgery. 2017; 12 (1): 5.

25. Huang S, Vohora A, Russ M, Mathew J, Johnny C, Stevens J, et al. Delaying urinary catheter insertion in the reception and resuscitation of blunt multitrauma and using a full bladder to tamponade pelvic bleeding. Injury. 2015; 46 (6): 1081-3.

26. Sokol K, Black G, Willey S, Song M, Marko S, Eckert M, et al. Preperitoneal balloon tamponade for lethal closed retroperitoneal pelvic hemorrhage in a swine model. Journal of Trauma and Acute Care Surgery. 2016; 81 (6): 1046-55.

\section{Литература}

1. Смоляр А. Н. Диагностика и лечение травматических забрюшинных кровоизлияний [диссертация]. М.: 2012-272.

2. Burkhardt $M$, Kristen $A$, Culemann $U$, Koehler D, Histing $T$, Holstein $\mathrm{J}$ et al. Pelvic fracture in multiple trauma: Are we still upto-date with massive fluid resuscitation? Injury. 2014; (45): 70-5.

3. Esmer E, Esmer E, Derst P, Schulz M, Siekmann H, Delank K. Einfluss der externen Beckenstabilisierung bei hämodynamisch instabilen Beckenfrakturen. Der Unfallchirurg. 2015; 120 (4): 312-9.

4. Wohlrath B, Trentzsch H, Hoffmann R, Kremer M, SchmidtHorlohè K, Schweigkofler U. Preclinical and clinical treatment of instable pelvic injuries: Results of an online survey. Der Unfallchirurg. 2014; 119 (9): 755-62. In German.

5. Holcomb J, del Junco D, Fox E, Wade C, Cohen M, Schreiber M, et al. The Prospective, Observational, Multicenter, Major Trauma Transfusion (PROMMTT) Study. JAMA Surgery. 2013; 48 (2): 27.

6. Guerado E, Bertrand M, Valdes L, Cruz E, Cano J. Resuscitation of Polytrauma Patients: The Management of Massive Skeletal Bleeding. The Open Orthopaedics Journal. 2015; 9 (1): 283-95.

7. Costantini T, Coimbra R, Holcomb J, Podbielski J, Catalano R, Blackburn A, et al. Current management of hemorrhage from severe pelvic fractures. Journal of Trauma and Acute Care Surgery. 2016; 80 (5): 717-25.

8. Burlew C, Moore E, Stahel P, Geddes A, Wagenaar A, Pieracci F, et al. Preperitoneal pelvic packing reduces mortality in patients with life-threatening hemorrhage due to unstable pelvic fractures. Journal of Trauma and Acute Care Surgery. 2017; 82 (2): 233-42.

9. Tesoriero R, Bruns B, Narayan M, Dubose J, Guliani S, Brenner M, et al. Angiographic embolization for hemorrhage following pelvic fracture. Journal of Trauma and Acute Care Surgery. 2017; 82 (1): 18-26.

10. Файн А. М. Диагностика и лечение тяжелых переломов костей таза у пострадавших с сочетанной и множественной травмой [диссертация]. М., 2017-238.

11. Guerado E, Medina A, Mata M, Galvan J, Bertrand M. Protocols for massive blood transfusion: when and why, and potential complications. European Journal of Trauma and Emergency Surgery. 2015; 42 (3): 283-95.

12. Margolies M, Ring E, Waltman A, Kerr W, Baum S. Arteriography in the Management of Hemorrhage from Pelvic Fractures. New England Journal of Medicine. 1972; 287 (7): 317-21.

13. Pohlemann T, Gansslen A, Bosch $U$, Tscherne H. The Technique of Packing for Control of Hemorrhage in Complex Pelvic Fractures. Techniques in Orthopaedics. 1994; 9 (4): 267-70.

14. Smith W, Moore E, Osborn P, Agudelo J, Morgan S, Parekh A, et al. Retroperitoneal Packing as a Resuscitation Technique for Hemodynamically Unstable Patients with Pelvic Fractures: Report of Two Representative Cases and a Description of Technique. The Journal of Trauma: Injury, Infection, and Critical Care. 2005; 59 (6): 1510-4.

15. Hughes C. W. Use of an intra-aortic balloon catheter tamponade for controlling intra-abdominal hemorrhage in man. Surgery. 1954; 36 (1): 65-8.

16. DuBose J, Scalea T, Brenner M, Skiada D, Inaba K, Cannon J et al. The AAST prospective Aortic Occlusion for Resuscitation in Trauma and Acute Care Surgery (AORTA) registry. Journal of Trauma and Acute Care Surgery. 2016; 81 (3): 409-19.

17. Matityahu A, Marmor M, Elson J, Lieber C, Rogalski G, Lin C, et al. Acute Complications of Patients With Pelvic Fractures After Pelvic Angiographic Embolization. Clinical Orthopaedics and Related Research. 2013; 471 (9): 2906-11

18. Salcedo E, Brown I, Corwin M, Galante J. Pelvic angioembolization in trauma - Indications and outcomes. International Journal of Surgery. 2016; (33): 231-6.

19. Rudloff M, Triantafillou K. Management of Pelvic Ring Injuries in Unstable Patients. Orthopedic Clinics of North America. 2016; 47 (3): 551-63.

20. Saito N, Matsumoto H, Yagi T, Hara Y, Hayashida K, Motomura T, et al. Evaluation of the safety and feasibility of resuscitative endovascular balloon occlusion of the aorta. Journal of Trauma and Acute Care Surgery. 2015; 78 (5): 897-904.

21. Davidson A, Russo R, Reva V, Brenner M, Moore L, Ball C, et al. The pitfalls of resuscitative endovascular balloon occlusion of the aorta. Journal of Trauma and Acute Care Surgery. 2018; 84 (1): 192-202.

22. Uchino H, Tamura N, Echigoya R, Ikegami T, Fukuoka T. "REBOA" Is it Really Safe? A Case with Massive Intracranial Hemorrhage Possibly due to Endovascular Balloon Occlusion of the Aorta (REBOA). American Journal of Case Reports. 2016; 17: 810-3.

23. Charoenkwan K. Effective use of the Bakri postpartum balloon for posthysterectomy pelvic floor hemorrhage. American Journal of Obstetrics and Gynecology. 2014; 210 (6): 586.

24. Coccolini F, Stahel P, Montori G, Biffl W, Horer T, Catena F, et al. Pelvic trauma: WSES classification and guidelines. World Journal of Emergency Surgery. 2017; 12 (1): 5.

25. Huang S, Vohora A, Russ M, Mathew J, Johnny C, Stevens J, et al. Delaying urinary catheter insertion in the reception and resuscitation of blunt multitrauma and using a full bladder to tamponade pelvic bleeding. Injury. 2015; 46 (6): 1081-3.

26. Sokol K, Black G, Willey S, Song M, Marko S, Eckert M, et al. Preperitoneal balloon tamponade for lethal closed retroperitoneal pelvic hemorrhage in a swine model. Journal of Trauma and Acute Care Surgery. 2016; 81 (6): 1046-55. 